\title{
КЛІНІКО-ЛАБОРАТОРНІ ПОКАЗНИКИ У ПАЦІЕНТІВ 3 НЕАЛКОГОЛЬНОЮ ЖИРОВОЮ ХВОРОБОЮ ПЕЧІНКИ НА ТЛІ ЕСЕНЦІАЛЬНОЇ АРТЕРІАЛЬНОЇ ГІПЕРТЕНЗІЇ
}

\author{
๑М. М. Гечко ${ }^{1}$, І. В. Чопей ${ }^{1}$, К. І. Чубірко ${ }^{1}$, К. О. Дебрецені', В. В. С. Руманех ${ }^{2}$ \\ ДВНЗ «Ужгородський національний університет»" \\ Сумський державний університет²
}

РЕЗЮМЕ. Неалкогольна жирова хвороба печінки (НАЖХП) є однією з найскладніших проблем сучасної медицини. Ї̈̈ перебіг часто коморбідний та пов'язаний з артеріальною гіпертензією і метаболічним синдромом. Слід зазначити, що в останні роки з'явилося багато робіт із вивчення НАЖХП, але залишаються нез'ясованими питання стосовно механізмів розвитку НАЖХП із есенціальною артеріальною гіпертензією, показників добового моніторингу АТ та вибору оптимального лікування, особливо з урахуванням хронобіологічних змін.

Мета дослідження - оптимізація діагностики та лікування НАЖХП на тлі артеріальної гіпертензії.

Матеріал і методи. Обстежено 167 хворих у віці 28-69 років які перебували на амбулаторному та стаціонарному лікуванні у ДЗ «Відділкова клінічна лікарня ст. Ужгород ДТГО «Львівська залізниця» протягом 20102019 років.

Результати. Встановлено погіршення показників ліпідного і вуглеводного обміну з підвищенням інтенсивності лабораторних синдромів цитолізу та холестазу, а також зміни циркадного ритму АТ у пацієнтів із НАЖХП на тлі АГ.

Висновки. Застосування хронотерапевтичних підходів, розвантажувально-дієтичної терапії, адеметіоніну, урсодезоксихолевої кислоти у різних підгрупах пацієнтів із НАЖХП та АГ, поряд із корекцією способу життя та базисною терапією (аторвастатин, телмісартан та індапамід), сприяє корекції основних змін досліджуваних лабораторних показників та відхилень АТ.

КлючОВІ СлОВА: неалкогольна жирова хвороба печінки; артеріальна гіпертензія; добовий моніторинг артеріального тиску; розвантажувально-дієтична терапія.

Вступ. Неалкогольна жирова хвороба печінки (НАЖХП) є однією з найскладніших проблем сучасної медицини, її перебіг часто коморбідний та пов'язаний з артеріальною гіпертензією та метаболічним синдромом [1]. НАЖХП та артеріальна гіпертензія (АГ) призводять до більш раннього ураження органів-мішеней та зростання смертності від серцево-судинних захворювань [2, 3]. 3олотим стандартом діагностики НАЖХП $\epsilon$ біопсія печінки з подальшим гістологічним дослідженням [4], але ця маніпуляція може призводити до ускладнень. Достатньо інформативним неінвазивним інструментальним методом діагностики НАЖХП є еластографія, яка дозволяє отримати об'єктивну інформацію про жорсткість тканини печінки [5]. За даними літератури, ФіброМакс $\epsilon$ ефективною альтернативою пункційній біопсії печінки $[6,7]$.

Сонографічне дослідження печінки $\epsilon$ безпечним, швидким та дешевим методом і дозволяє проводити дослідження в динаміці. До діагностичних обмежень належать низька чутливість при початковому стеатозі, при значному ожирінні, неможливість диференціювати неалкогольний стеатогепатит (НАСГ) та стеатоз та суб'єктивність методу [8]. За даними літератури, в залежності від цих факторів та від технічних характеристик обладнання, чутливість методу коливається в межах 59-93 \%, а специфічність - 70-96 \% [9]. Ці показни- ки також залежать від ступеня ожиріння печінки [10]. Важливими сонографічними діагностичними критеріями НАЖХП $\epsilon$ гепатомегалія, підвищення ехогенності печінки, зміни показників індексу резистентності та пульсаційного індексу печінкової артерії тощо [11]. 3 іншого боку, в літературі зустрічаються суперечливі дані щодо зв'язку цих показників з індексом маси тіла, ступенем інфільтрації жиру в печінці та коморбідності НАЖХП та АГ $[12,13]$.

Високоінформативним інструментальним методом діагностики стеатозу печінки $\epsilon$ комп'ютерна томографія (КТ). За чутливістю методика досягає 43-95\%, а за специфічністю 90 \% [14]. Метод не використовується широко через високу вартість та значне променеве навантаження. До інших недоліків КТ належать неможливість диференціювати фіброз та запалення печінки [15].

Чутливість та специфічність магнітно-резонансної томографії (МРТ) складає, відповідно, 81 \% та $100 \%$. При цьому визначається не тільки наявність жиру, а і його кількість [15]. Втім, за допомогою МРТ неможливо діагностувати НАСГ [16]. Із сучасних неінвазивних методів, що дозволяють визначити хімічний склад печінки та активність метаболічних процесів, належить МРТ-спектроскопія [15].

Із спільних механізмів НАЖХП та артеріальної гіпертензії заслуговують на увагу інсулінорезистентність (IP), порушення ліпідного та вугле- 
Огляди літератури, оригінальні дослідження, погляд на проблему, випадок з практики, короткі повідомлення водного обміну, оксидативний стрес та запалення, генетичні фактори тощо [17].

При коморбідності НАЖХП та АГ важливим $\epsilon$ процес ремоделювання лівого шлуночка (ЛШ). Основним методом діагностики гіпертрофії лШ $\epsilon$ розрахунок індексу маси міокарда ЛШ, причому

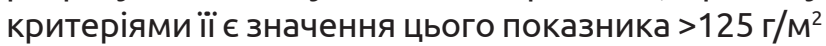
для чоловіків та 110 >г/м² для жінок [18].

В останні роки з'явилося багато робіт із вивчення НАЖХП, але не вивченими залишаються питання стосовно механізмів розвитку НАЖХП із есенціальною артеріальною гіпертензією, в тому числі показників добового моніторингу АТ з урахуванням хронобіологічних змін та вибору оптимального лікування.

Якщо терапія АГ вивчена досить добре, існують та щорічно переглядаються рекомендації щодо лікування [19], то вибір медикаментозних засобів з доведеною ефективністю при НАЖХП $\epsilon$ досить обмеженим. Згідно з останніми міжнародними рекомендаціями, базовим методом лікування НАЖХП без стеатогепатиту є зміна способу життя, що включає дієту, корекцію маси тіла та відповідне фізичне навантаження. Цей постулат підтверджують нещодавні дослідження $[20,21]$. Кількість препаратів, що тривало використовуються при лікуванні НАЖХП, обмежена: вітамін Е, обетіхолієва кислота та піоглітазон, але два останні можуть призводити до гіперліпідемії та ожиріння відповідно. Таким чином, на сучасному етапі найкраще лікування НАЖХП базується на комбінованій терапії немедикаментозними методами та індивідуально підібраною базисною терапією. Комбінація лікарських препаратів при НАЖХП повинна мати протизапальний та антифібротичний ефект. Більшість авторів рекомендують при коморбідній патології АГ та НАЖХП комбінацією препаратів із статинів, сартанів [15, 22-24] у поєднанні з урсодезоксихолевою кислотою [24-26] та поліненасиченими жирними кислотами [27].

Мета - оптимізація діагностики та лікування НАЖХП на тлі артеріальної гіпертензії.

Ми поставили перед собою завдання дослідити особливості метаболічних порушень ліпідного та вуглеводного обміну; вивчити особливості добового профілю артеріального тиску; оцінити ефективність різних схем комплексного лікування НАЖХП та АГ, в тому числі з урахуванням хронобіологічних підходів.

Матеріал і методи дослідження. Відповідно до мети та завдань дослідження впродовж 20102019 років проведено обстеження та лікування пацієнтів, які перебували на амбулаторному та стаціонарному лікуванні у Д3 «Відділкова клінічна лікарня ст. Ужгород ДТГО «Львівська залізниця» (реструктуризована у КНП «Ужгородська клінічна районна лікарня УРР 30»).

Усі пацієнти дали письмову інформовану згоду відповідно до етичних норм Хельсінкської декларації. До включення у дослідження проводився аналіз критеріїв включення на основі скарг та анамнезу. Обстежено 167 хворих у віці 28-69 років. Усі пацієнти були поділені на три групи. Перша група - основна - хворі з НАЖХП та АГ (n=90), та дві групи порівняння - хворі з НАЖХП без АГ (n=53) і хворі з АГ без НАЖХП (n=24). Контрольну групу складали практично здорові особи аналогічної вікової та статевої категорій $(n=18)$. Середній вік пацієнтів склав $(49,54 \pm 11,25)$ років, розподіл за статтю був рівномірним.

Як видно з таблиці 1, виявлено достовірні відмінності антропометричних показників пацієнтів із групи НАЖХП у порівнянні з контрольною групою осіб. Розрахунок загального відсотка жиру в організмі (BF) свідчить про наявність ожиріння у пацієнтів цієї групи та підвищення індексу ожиріння тіла (BAI). Для визначення типу ожиріння оцінювали обвід талії (ОТ) та відношення ОТ до обводу стегон, яке показало переважання абдомінального типу ожиріння.

Таблиця 1. Характеристика антропометричних показників у пацієнтів з неалкогольною жировою хворобою печінки у поєднанні з артеріальною гіпертензією (M士m)

\begin{tabular}{|c|c|c|c|}
\hline \multicolumn{2}{|c|}{ Показники } & $\begin{array}{c}\mathrm{HA} Ж X П+\mathrm{A} Г \\
\mathrm{n}=90\end{array}$ & $\begin{array}{c}\text { Контрольна група } \\
\mathrm{n}=18\end{array}$ \\
\hline \multicolumn{2}{|c|}{ Маса тіла (середня), кг } & $95,52 \pm 4,53$ & $71,52 \pm 1,96$ \\
\hline \multicolumn{2}{|c|}{ Зріст, см } & $172,3 \pm 7,2$ & $172,3 \pm 7,2$ \\
\hline \multirow{2}{*}{ Стать } & чоловіки & $48(53,33 \%)$ & $10(56,56 \%)$ \\
\hline & жінки & $42(46,67 \%)$ & $8(44,44 \%)$ \\
\hline \multicolumn{2}{|c|}{$\mathrm{IMT}, \mathrm{kr} / \mathrm{M}^{2}$} & $32,34 \pm 2,72$ & $23,42 \pm 1,9$ \\
\hline \multicolumn{2}{|l|}{ OT, $\mathrm{CM}$} & $118,22 \pm 7,26$ & $78,23 \pm 6,12$ \\
\hline \multicolumn{2}{|c|}{$\mathrm{OC}, \mathrm{CM}$} & $113,74 \pm 6,32$ & $90,97 \pm 3,24$ \\
\hline \multicolumn{2}{|c|}{ ОТ/ОС, Од } & $1,04 \pm 0,28$ & $0,86 \pm 0,39$ \\
\hline \multicolumn{2}{|l|}{$\mathrm{BF}, \%$} & $45,7 \pm 4,8$ & $33,8 \pm 1,9$ \\
\hline \multicolumn{2}{|l|}{ BAI, $\%$} & $35,8 \pm 3,8$ & $27,4 \pm 2,5$ \\
\hline
\end{tabular}


Огляди літератури, оригінальні дослідження, погляд на проблему, випадок з практики, короткі повідомлення

Пацієнти основної групи мали надлишкову масу тіла (38,25\%), ожиріння І ступеня $(46,72 \%)$, ожиріння ІІ ступеня (10,32 \%) та ожиріння III ступеня (4,71\%). Відповідно до мети і завдань дослідження пацієнтів основної групи обстежували додатково через 3 та 12 місяців. При цьому добовий моніторинг артеріального тиску (ДМАТ) проводили чотири рази на рік - у весняний, літній, осінній та зимовий періоди.

Лікування хворих розпочинали з дієтотерапії, спрямованої на зниження маси тіла, рівнів тригліцеридів, лПнЩ та нормалізацію показників АТ до цільових рівнів. Хворим також були рекомендовані щоденні прогулянки тривалістю не менше 1 години з проходженням більше 10000 кроків за день. Основна група (НАЖХП з АГ, n=90) була поділена на п'ять підгруп, по 18 пацієнтів у кожній, залежно від варіанта терапії. Хворі 1-4 підгруп отримували базисну терапію (БТ): телмісартан (40 мг/добу) у поєднанні з індапамідом (2,5 мг/добу) та аторвастатин (20 мг/добу) протягом року. Пацієнти підгрупи 1 отримували тільки БТ, підгрупи 2 БТ та урсодезоксихолеву кислоту (10 мг/кг/день), підгрупи 3 - БТ та адеметіонін - STEP-терапія (1000 мг/добу внутрішньовенно 14 днів з подальшим переходом на таблетки по 500 мг 2 рази/ день 3 місяці), підгрупи 4 - БТ, при якій препарати призначалися з урахуванням добового ритму артеріального тиску на підставі показників ДМАТ, підгрупи 5 - тільки розвантажувально-дієтичну терапію з дозованим фізичним навантаженням без БТ.

Пацієнтам усіх груп проводили комплексне клінічне обстеження. Діагноз встановлювали на підставі скарг, анамнезу, даних об'єктивного обстеження, результатів лабораторних та інструментальних досліджень.

Фізикальне обстеження пацієнтів включало вимірювання зросту, маси тіла та розрахунок IMT. Окрім цього, пацієнтам проводили клінічні аналізи крові та сечі. Визначали також концентрацію глюкози венозної крові натще, загальний білірубін та його фракції, сечовину та креатинін сироватки крові, активність печінкових ферментів, ліпідів, концентрацію інсуліну в сироватці крові, рівень глікозильованого гемоглобіну та НОМАіндекс.

Усі отримані результати обробляли методами варіаційної статистики з використанням комп'ютерної програми «STATISTICA». Дані були представлені у загальноприйнятому вигляді $(\mathrm{M} \pm \mathrm{m})$, де $\mathrm{M}$ середнє арифметичне, а $\mathrm{m}$ - середньоквадратичне відхилення. Результати вважали статистично значущими при вірогідності помилки менше п'яти відсотків $(p<0,05)$.

Результати й обговорення. Результати біохімічного дослідження крові пацієнтів представлені в таблиці 2.

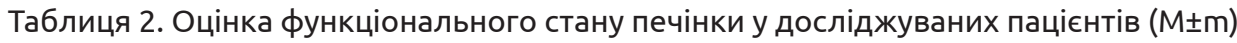

\begin{tabular}{|c|c|c|c|c|}
\hline \multirow[b]{2}{*}{ Показник } & \multicolumn{3}{|c|}{ Групи хворих } & \multirow{2}{*}{$\begin{array}{c}\text { Група контролю } \\
\mathrm{n}=18\end{array}$} \\
\hline & $\begin{array}{c}\text { HAЖXП, } \\
\mathrm{n}=53\end{array}$ & $\begin{array}{l}\text { НАЖXП+АГ, } \\
n=90\end{array}$ & $\begin{array}{c}\mathrm{A} \Gamma \\
\mathrm{n}=24\end{array}$ & \\
\hline АлТ, Од/л & $32,4 \pm 15,8^{*} \&$ & $38,2 \pm 16,8^{* \&}$ & $22,1 \pm 11,9$ & $13,6 \pm 7,2$ \\
\hline АСТ, Од/л & $32,7 \pm 15,2^{* \&}$ & $39,8 \pm 17,9 * \&$ & $22,7 \pm 5,2$ & $9,3 \pm 4,9$ \\
\hline ЛФ, Од/л & $51,33 \pm 14,8$ & $104,8 \pm 24,2^{*} \#^{\&}$ & $42,2 \pm 12,3$ & $46,6 \pm 8,4$ \\
\hline ГГТП, Од/л & $31,7 \pm 14,8^{*} \&$ & $44,3 \pm 12,6^{* \&}$ & $14,7 \pm 5,4$ & $15,2 \pm 4,6$ \\
\hline $\begin{array}{l}\text { Білірубін загальний, } \\
\text { мкмоль/л }\end{array}$ & $13,4 \pm 3,9$ & $12,1 \pm 4,5$ & $9,8 \pm 2,8$ & $10,2 \pm 2,9$ \\
\hline $\begin{array}{l}\text { Білірубін прямий, } \\
\text { мкмоль/л }\end{array}$ & $4,4 \pm 1,2$ & $3,8 \pm 1,1$ & $2,9 \pm 0,8$ & $3,4 \pm 0,7$ \\
\hline
\end{tabular}

Примітка. * - статистично значущі відмінності відносно групи контролю; \# - статистично значущі відмінності відносно групи НАЖХП; \& - статистично значущі відмінності відносно групи ГХ.

Функціональний стан печінки оцінювали за допомогою лабораторних показників цитолізу та холестазу: аланінамінотрансферази (АЛТ), аспартатамінотрансферази (АСТ), гаммаглутаматтранспептидази (ГГТП), рівнів білірубіну та лужної фосфатази (ЛФ).

При аналізі даних, наведених в таблиці 2, встановлено вірогідну різницю між досліджуваною та контрольною групами хворих за показниками трансаміназ та ГГТП, хоча останні були в межах норми.
Із наведених результатів лабораторного дослідження видно, що у хворих із НАЖХП порушений не тільки вуглеводний обмін, що проявляється підвищенням рівня інсуліну, індексу НОМА, глікозильованого гемоглобіну $(p<0,05)$, а й ліпідний обмін, що проявлялося достовірними змінами рівня тригліцеридів, ЛПВЩ, коефіцієнта атерогенності та рівня загального холестерину (р<0,05) (табл. 3).

За даними ДМАТ, у хворих на НАЖХП із АГ виявлено підвищення пульсового АТ (ПАТ), як удень, 
Огляди літератури, оригінальні дослідження, погляд на проблему, випадок з практики, короткі повідомлення

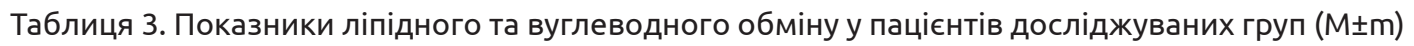

\begin{tabular}{|c|c|c|c|c|}
\hline \multirow[b]{2}{*}{ Показники } & \multicolumn{3}{|c|}{ Групи хворих } & \multirow{2}{*}{$\begin{array}{l}\text { Контрольна } \\
\text { група, n=18 }\end{array}$} \\
\hline & $\begin{array}{c}\text { HAЖXП, } \\
n=53\end{array}$ & $\begin{array}{c}\mathrm{HA} Ж X \Pi+\mathrm{A} Г \\
\mathrm{n}=90\end{array}$ & $\begin{array}{c}\mathrm{A \Gamma}, \\
\mathrm{n}=24\end{array}$ & \\
\hline Глюкоза, ммоль/л & $5,5 \pm 0,6 * \&$ & $5,7 \pm 0,5 * \&$ & $4,6 \pm 0,5$ & $4,1 \pm 0,6$ \\
\hline Інсулін, мкОд/мл & $12,6 \pm 2,7$ *\& & $14,9 \pm 1,2 * \&$ & $9,1 \pm 2,8$ & $7,9 \pm 1,4$ \\
\hline HOMA-IR & $5,6 \pm 2,8 * \&$ & $5,7 \pm 2,2 * \&$ & $3,9 \pm 1,1 *$ & $2,1 \pm 0,2$ \\
\hline Глікозильований гемоглобін, \% & $5,9 \pm 0,7 *$ & $5,7 \pm 0,3 *$ & $5,5 \pm 0,8 *$ & $5,1 \pm 0,3$ \\
\hline ЗХС, ммоль/л & $5,6 \pm 0,6 *$ & $5,8 \pm 0,9 *$ & $5,4 \pm 0,3 *$ & $4,2 \pm 0,6$ \\
\hline ТГ, ммоль/л & $2,2 \pm 0,4^{* \# \&}$ & $2,5 \pm 0,6 * \&$ & $2,0 \pm 0,4^{*}$ & $1,3 \pm 0,2$ \\
\hline лП ДНЩ, ммоль/л & $0,6 \pm 0,2$ & $0,8 \pm 0,4$ & $0,6 \pm 0,2$ & $0,8 \pm 0,1$ \\
\hline ЛПВЩ, ммоль/л & $1,1 \pm 0,1^{*}$ & $1,2 \pm 0,1 *$ & $1,2 \pm 0,2^{*}$ & $2,1 \pm 0,7$ \\
\hline ЛПНЩ, ммоль/л & $3,8 \pm 0,5^{*}$ & $3,9 \pm 0,4^{*}$ & $3,7 \pm 0,5^{*}$ & $2,5 \pm 0,3$ \\
\hline KA & $4,0 \pm 1,2 * \&$ & $3,81 \pm 1,1 * \&$ & $3,4 \pm 1,1^{*}$ & $0,8 \pm 0,4$ \\
\hline Загальний білок, г/л & $71,4 \pm 1,8$ & $71,8 \pm 2,1$ & $70,6 \pm 2,2$ & $72,5 \pm 2,4$ \\
\hline Сечова кислота, Ммоль/л & $295,3 \pm 33,4$ & $332,4 \pm 42,2$ & $284,8 \pm 19,6$ & $260,2 \pm 12,3$ \\
\hline С-реактивний білок, мг/л & $4,2 \pm 0,5$ & $4,4 \pm 0,4$ & $4,1 \pm 0,2$ & $4,0 \pm 0,3$ \\
\hline
\end{tabular}

Примітка. * - статистично значущі відмінності відносно групи контролю; \# - статистично значущі відмінності відносно групи НАЖХП; \& - статистично значущі відмінності відносно групи ГХ.

так і вночі, а також підвищення швидкості ранкового підйому АТ, що є несприятливим фактором ризику серцево-судинних ускладнень. Підвищена варіабельність систолічного артеріального тиску (САТ) виявлена у $67 \%$ осіб у групі НАЖХП із АГ $(p<0,05) .3$ іншого боку, підвищена нічна варіабельність САТ відмічена у кожного п'ятого пацієнта. Кількість пацієнтів основної групи із добовим профілем «non dipper» склала 48 \% проти 33 \% у групі НАЖХП без АГ. Добові профілі АТ «night peacker» та "overdipper» спостерігалися в одиничних випадках. Слід зазначити, що найбільш виражені зміни показників ДМАТ спостерігалися у першому та третьому кварталах року.

На підставі отриманих результатів можна зробити висновок, що пацієнти основної групи мають більше факторів кардіоваскулярного ризику, ніж пацієнти із НАЖХП без АГ.

При порівняльному аналізі ефективності лікування пацієнтів різних підгруп основної групи встановлено покращення антропометричних показників у всіх підгрупах, при цьому індекс маси тіла достовірно зменшився у хворих 5 підгрупи

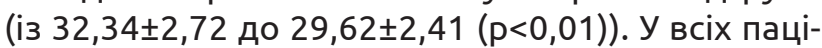
єнтів відмічалося статистично достовірне зниження офісного САТ (із $(168,3 \pm 4,9)$ до $(132,4 \pm 3,9)$ мм рт. ст. $(p<0,01))$ та ДАТ (із $(103,1 \pm 3,8)$ до $(76,4 \pm 4,2)$ мм рт. ст. $(p<0,01))$. Слід зазначити, що основні показники ДМАТ також мали тенденцію до нормалізації.

Статистично достовірно показано покращення показників ліпідограми. Проатерогенні показники знизилися, а ЛПВЩ мали тенденцію до підвищення $(p<0,05)$. Не виявлено достовірних від- мінностей показників білірубіну та його фракцій, а також рівнів сечової кислоти та С-реактивного білка. Слід відмітити покращення показників вуглеводного обміну. Так, HOMA-IR суттєво знизився, з 5,7 $\pm 2,2$ до $3,5 \pm 0,4(p<0,05)$.

Порівняльний аналіз ефективності лікування у 2 та 3 підгрупах показав позитивний вплив обох схем терапії на рівні глюкози натще, глікозильованого гемоглобіну та індексу інсулінорезистентності і позитивні зміни ліпідограми. Слід також вказати, що обидві схеми у цих підгрупах приводили до зниження активності АЛТ, АСТ, ГГТП та ЛФ (p<0,05). Виявлена динаміка свідчить про позитивний гепатопротекторний вплив, що проявляється у зменшенні інтенсивності синдромів цитолізу та холестазу. Окрім цього, виявлено зростання рівня загального білка та зниження рівня сечової кислоти, що вказує на позитивний вплив цих препаратів на пуриновий обмін у пацієнтів вказаних підгруп, а позитивний вплив на ліпідний обмін у групі НАЖХП без АГ практично не відрізняється від дії аторвастатину у 1 підгрупі.

Висновки. При НАЖХП з АГ спостерігаєТься посилення метаболічних порушень, при цьому достовірно підвищуються значення HOMA-IR та рівні тригліцеридів, що свідчить про високий атерогенний потенціал у цих пацієнтів і може призводити до зростання кардіоваскулярного ризику. Про це також свідчать показники ДМАТ, у тому числі у перший та третій квартали року.

Включення у терапевтичний комплекс, поряд з модифікацією способу життя та корекцією харчового раціону, медикаментозного лікування 
Огляди літератури, оригінальні дослідження, погляд на проблему, випадок з практики, короткі повідомлення із застосуванням базисної терапії (аторвастатин, телмісартан та індапамід) з урахуванням циркадного ритму АТ, урсодезоксихолевої кислоти, адеметіоніну, розвантажувально-дієтичної терапії, приводить до покращення лабораторних показників, оскільки сприяє не тільки корекції лабораторних синдромів цитолізу та холестазу, а й ко-

регує дисліпідемію та знижує вміст тригліцеридів.

Перспективи подальших досліджень. Наші подальші дослідження будуть спрямовані на вивчення шляхів оптимізації діагностики і лікування неалкогольної жирової хвороби печінки на тлі артеріальної гіпертензії.

\section{ЛІТЕРАТУРА}

1. Коморбідність і високий кардіоваскулярний ризик - ключові питання сучасної медицини / Г. Д. Фадєєнко, О. Гріднєв, А. Несен [та ін.] // Український терапевтичний журнал. - 2013. - № 1. - С. 102-107.

2. Степанов Ю. М. Результати обсерваційного перехресного дослідження PRELID 2 (2015-2016). Частина 1. Поширеність неалкогольної жирової хвороби печінки, характеристика супутньої патології, метаболічного синдрому та його окремих критеріїв у пацієнтів, які звертаються до терапевтів і гастроентерологів в Україні / Ю. М. Степанов // Гастроентерологія. - 2019. - № 53 (1). C. 26-33.

3. Bellentani S. The epidemiology of non-alcoholic fatty liver disease / S. Bellentani // Liver Int. - 2017. Vol. 37 (Suppl 1). - P. 81-84. DOI: 10.1111/liv.13299.

4. Histological severity and clinical outcomes of nonalcoholic fatty liver disease in nonobese patients / J. C. Leung, T. C. Loong, J. L. Wei [et al.] // Hepatology. 2017. - Vol. 65 (1). - P. 54-64. DOI: 10.1002/hep.28697.

5. Diagnosis and management of non-alcoholic fatty liver disease / E. Jennison, J. Patel, E. Scorletti, C. D. Byrne // Postgrad. Med. J. - 2019. - Vol. 95 (1124). - P. 314-322.

6. Diagnostic performance of FibroTest, SteatoTest and ActiTest in patients with NAFLD using the SAF score as histological reference / M. Munteanu, D. Tiniakos, Q. Anstee [et al.] // Aliment Pharmacol. Ther. - 2016. - Vol. 44 (8). P. 877-889. DOI: 10.1111/apt.13770.

7. Vilar-Gomez E. Non-invasive assessment of nonalcoholic fatty liver disease: clinical prediction rules and blood-based biomarkers / E. Vilar-Gomez, N. Chalasani // J. Hepatol. - 2018. - Vol. 68 (2). - P. 305-315. DOI: 10.1016/j.jhep.2017.11.013.

8. Ultrasound-based tissue characterization and classification of fatty liver disease: A screening and diagnostic paradigm / U. R. Acharya, O. Faust, F. Molinari [et al.] // Knowledge-Based Systems. - 2015. - Vol. 75. - P. 66-77. DOI: https://doi.org/10.1016/j.knosys.2014.11.021.

9. Noninvasive assessment of liver steatosis using ultrasound methods / M. Lupşor-Platon, H. Stefănescu, D. Mureșan [et al.]// Med. Ultrason. - 2014. - Vol. 16 (3). P. 236-245. DOI: 10.11152/mu.2013.2066.163.1mlp.

10. Журавлева Л. В. Преимущества и недостатки современных методов диагностики неалкогольной жировой болезни печени / Л. В. Журавлева, Е. В. Огнева // Український медичний вісник. - 2014. - № 10. - С. 19-21.

11. Hepatic artery and portal vein doppler indexes in non-alcoholic fatty liver disease before and after treatment to prevent unnecessary health care costs / M. K. Tarzamni, M. Khoshbaten, S. Sadrarhami [et al.] // Int. J. Prev. Med. 2014. - Vol. 5 (4). - P. 472-427.
12. Effects of diffuse fatty infiltration of the liver on portal vein flow hemodynamics / A. Balci, S. Karazincir, H. Sumbas [et al.] // J. Clin. Ultrasound. -2008. - Vol. 36 (3). P. 134-140. DOI: 10.1002/jcu.20440.

13. Effect of severity of steatosis as assessed ultrasonographically on hepatic vascular indices in non-alcoholic fatty liver disease / A. Mohammadi, M. Ghasemi-rad, H. Zahedi [et al.] // Med. Ultrason. - 2011. - Vol. 13 (3). - P. 200-206.

14. Computed tomography measurement of hepatic steatosis: Prevalence of hepatic steatosis in a Canadian population / M. M. Wells, Z. Li, B. Addeman [et al.] // Can. J. Gastroenterol. Hepatol. - 2016. - Vol. 2016. - 4930987. DOI: $10.1155 / 2016 / 4930987$.

15. Paredes A. H. Nonalcoholic fatty liver disease / A. H. Paredes, D. M. Torres, S. A. Harrison // Clin. Liver Dis. 2012.-Vol. 16 (2).-P. 397-419. DOI: 10.1016/j.cld.2012.03.005.

16. MRI steatosis grading: development and initial validation of a color mapping system / A. Qayyum, M. Nystrom, S. M. Noworolski [et al.] // Am. J. Roentgenol. -2012.Vol. 198 (3). - P. 582-588.

17. Adipokines and non-alcoholic fatty liver disease: multiple interactions / T. E. Adolph, C. Grander, F. Grabherr, H. Tilg // Int. J. Mol. Sci. - 2017. - Vol. 18 (8). - P. 1649. DOI: $10.3390 /$ ijms18081649.

18. Shah A. M. Left ventricular size, mass, and shape: is the sum greater than the parts? / A. M. Shah, M. A. Pfeffer // JACC Heart Fail. - 2014. - Vol. 2 (5). - P. 523-525. DOI: $10.1016 /$ j.jchf.2014.05.010.

19. 2018 ESC/ESH guidelines for the management of arterial hypertension: the Task Force for the management of arterial hypertension of the European Society of Cardiology and the European Society of Hypertension / B. Williams, G. Mancia, W. Spiering [et al.] // J. Hypertens. -2018. Vol. 36 (10). - P. 1953-2041.

20. European Association for the Study of the Liver (EASL); European Association for the Study of Diabetes (EASD); European Association for the Study of Obesity (EASO). EASL-EASD-EASO Clinical Practice Guidelines for the management of non-alcoholic fatty liver disease // Diabetologia. - 2016. - Vol. 59 (6). - P. 1121-1140. DOI: 10.1007/s00125-016-3902-y.

21. Romero-Gómez M. Treatment of NAFLD with diet, physical activity and exercise / M. Romero-Gómez, S. ZelberSagi, M. Trenell // J. Hepatol. - 2017. - Vol. 67 (4). - P. 829846. DOI: 10.1016/j.jhep.2017.05.016.

22. Blood Pressure and Cholesterol-lowering Efficacy of a Fixed-dose Combination With Irbesartan and Atorvastatin in Patients With Hypertension and Hypercholesterolemia: A Randomized, Double-blind, Factorial, Multicenter Phase III Study / S. H. Kim, S. H. Jo, S. C. Lee [et al.] // Clin. 
Огляди літератури, оригінальні дослідження, погляд на проблему, випадок з практики, короткі повідомлення Ther. - 2016. - Vol. 38 (10). - P. 2171-2184. DOI: 10.1016/j.clinthera.2016.09.005.

23. Diagnosis, prevention, and management of statin adverse effects and intolerance: Canadian Consensus Working Group update / G. B. Mancini, S. Baker, J. Bergeron [et al.] // Can. J. Cardiol. - 2016. - Vol. 32 (7 Suppl). - P. S35-65. DOI: 10.1016/j.cjca.2016.01.003.

24. Клинические рекомендации по диагностике и лечению неалкогольной жировой болезни печени Российского общества по изучению печени и Российской гастроэнтерологической ассоциации / В. Т. Ивашкин, М. В. Маевская, Ч. С. Павлов [и др.] // Гепатология. 2015. - № 2 (16). - С. 24-42.

\section{REFERENCES}

1. Fadieienko, H.D., Hridniev, O., Nesen, A., Chernyshov, V., Hrunchenko, M., \& Shkapo, V. (2013). Komorbidnist i vysokyi kardiovaskuliarnyi ryzyk - kliuchovi pytannia suchasnoi medytsyny [Comorbidity and high cardiovascular risk - key issues of modern medicine]. Ukrainskyi terapevtychnyi zhurnal - Ukrainian Therapeutic Journal, 1, 102-107 [in Ukrainian].

2. Stepanov, Yu.M. (2019). Rezultaty observatsiynoho perekhresnoho doslidzhennia PRELID 2 (2015-2016). Chastyna 1. Poshyrenist nealkoholnoi zhyrovoi khvoroby pechinky, kharakterystyka suputnoi patolohii, metabolichnoho syndromu ta yoho okremykh kryteriiv u patsiientiv, yaki zvertaiutsia do terapevtiv i hastroenterolohiv v Ukraini [Results of the observational cross-sectional study PRELID 2 (2015-2016). Part 1. Prevalence of non-alcoholic fatty liver disease, characteristics of concomitant pathology, metabolic syndrome and its individual criteria in patients who turn to therapists and gastroenterologists in Ukraine]. Hastroenterolohiya - Gastroenterology, 53 (1), 26-33 [in Russian].

3. Bellentani, S. (2017). The epidemiology of non-alcoholic fatty liver disease. Liver Int., 37, 81-84. DOI: 10.1111/ liv.13299

4. Leung, J.C., Loong, T.C., Wei, J.L., Wong, G.L., Chan, A.W., Choi, P.C., \& Wong, V.W. (2017). Histological severity and clinical outcomes of nonalcoholic fatty liver disease in nonobese patients. Hepatology, 65(1), 54-64. DOI: 10.1002/hep.28697

5. Jennison, E., Patel, J., Scorletti, E., \& Byrne, C.D. (2019). Diagnosis and management of non-alcoholic fatty liver disease. Postgrad. Med. J., 95(1124), 314-322. DOI: 10.1136/postgradmedj-2018-136316

6. Munteanu, M., Tiniakos, D., Anstee, Q., Charlotte, F., Marchesini, G., Bugianesi, E., \& Poynard, T. (2016). Diagnostic performance of FibroTest, SteatoTest and ActiTest in patients with NAFLD using the SAF score as histological reference. Aliment Pharmacol. Ther., 44(8), 877-889. DOI: 10.1111/apt.13770

7. Vilar-Gomez, E., \& Chalasani, N. (2018). Non-invasive assessment of non-alcoholic fatty liver disease: clinical prediction rules and blood-based biomarkers. J. Hepatol., 68 (2), 305-315. DOI: 10.1016/j.jhep.2017.11.013

8. Rajendra Acharya, U., Faust, O., Molinari, F., Sree, S.V., Junnarkar, S.P., \& Sudarshan, V. (2015). Ultrasound-based tissue characterization and classification of fatty liver disease: A screening and diagnostic paradigm.

Knowledge-Based Systems, 75, 66-77. DOI: https://doi. org/10.1016/j.knosys.2014.11.021

9. Lupşor-Platon, M., Stefănescu, H., Mureșan, D., Florea, M., Szász, M.E., Maniu, A., \& Badea, R. (2014). Noninvasive assessment of liver steatosis using ultrasound methods. Med. Ultrason., 16 (3), 236-245. DOI: 10.11152/ mu.2013.2066.163.1 mlp

10. Zhuravleva, L.V., \& Ogneva, Ye.V. (2014). Preimushchestva i nedostatki sovremennykh metodov diagnostiki nealkogolnoy zhirovoy bolezni pecheni [Advantages and disadvantages of modern methods of diagnostics of non-alcoholic fatty liver disease]. Ukrainskyi medychnii visnyk - Ukrainian Medical Bulletin, 10, 19-21 [in Russian].

11. Tarzamni, M.K., Khoshbaten, M., Sadrarhami, S., Daneshpajouhnejad, P., Jalili, J., Gholamian, M., \& Shahmoradi, Z. (2014). Hepatic artery and portal vein doppler indexes in non-alcoholic fatty liver disease before and after treatment to prevent unnecessary health care costs. Int. J. Prev. Med., 5 (4), 472-427.

12. Balci, A., Karazincir, S., Sumbas, H., Oter, Y., Egilmez, E., \& Inandi, T. (2008). Effects of diffuse fatty infiltration of the liver on portal vein flow hemodynamics. J. Clin. Ultrasound., 36 (3), 134-140. DOI: 10.1002/jcu.20440

13. Mohammadi, A., Ghasemi-rad, M., Zahedi, H., Toldi, G., \& Alinia, T. (2011). Effect of severity of steatosis as assessed ultrasonographically on hepatic vascular indices in non-alcoholic fatty liver disease. Med. Ultrason., 13 (3), 200-206.

14. Wells, M.M., Li, Z., Addeman, B., McKenzie, C.A., Mujoomdar, A., Beaton, M., \& Bird, J. (2016). Computed tomography measurement of hepatic steatosis: Prevalence of hepatic steatosis in a Canadian population. Can. J. Gastroenterol. Hepatol., 2016, 4930987. DOI: 10.1155/2016/4930987

15. Paredes, A.H., Torres, D.M., \& Harrison, S.A. (2012). Nonalcoholic fatty liver disease. Clin. Liver Dis., 16 (2), 397419. DOI: 10.1016/j.cld.2012.03.005

16. Qayyum, A., Nystrom, M., Noworolski, S.M., Chu, P., Mohanty, A., \& Merriman, R. (2012). MRI steatosis grading: development and initial validation of a color mapping system. Am. J. Roentgenol., 198(3), 582-588. DOI: 10.2214/AJR.11.6729

17. Adolph, T.E., Grander, C., Grabherr, F., \& Tilg, H. (2017). Adipokines and non-alcoholic fatty liver disease: multiple interactions. Int. J. Mol. Sci., 18(8), 1649. DOI: 10.3390/ijms18081649 
Огляди літератури, оригінальні дослідження, погляд на проблему, випадок з практики, короткі повідомлення

18. Shah, A.M., \& Pfeffer, M.A. (2014). Left ventricular size, mass, and shape: is the sum greater than the parts? JACC Heart Fail., 2 (5), 523-525. DOI: 10.1016/j.jchf.2014.05.010

19. Williams, B., Mancia, G., Spiering, W., Rosei, E.A., Azizi, M., Burnier, M., \& Desormais, I. (2018). 2018 ESC/ESH guidelines for the management of arterial hypertension: the Task Force for the management of arterial hypertension of the European Society of Cardiology and the European Society of Hypertension. J. Hypertens., 36 (10), 19532041. DOI: 10.1097/HJH.0000000000001940

20. (2016). European Association for the Study of the Liver (EASL); European Association for the Study of Diabetes (EASD); European Association for the Study of Obesity (EASO). EASL-EASD-EASO Clinical Practice Guidelines for the management of non-alcoholic fatty liver disease. Diabetologia, 59 (6), 1121-1140. DOI: 10.1007/s00125-0163902-y

21. Romero-Gómez, M., Zelber-Sagi, S., \& Trenell, M. (2017). Treatment of NAFLD with diet, physical activity and exercise. J. Hepatol., 67 (4), 829-846. DOI: 10.1016/j. jhep.2017.05.016

22. Kim, S.-H., Jo, S.-H., Lee, S.-C., Lee, S.-Y., Yoon, M.-H. Lee, H.-L., \& Oh, B.-H. (2016). Blood pressure and cholesterol-lowering efficacy of a fixed-dose combination with irbesartan and atorvastatin in patients with hypertension and hypercholesterolemia: a randomized, double-blind, factorial, multicenter phase III study. Clin. Ther., 38 (10), 2171-2184. DOI: 10.1016/j.clinthera.2016.09.005
23. Mancini, G.B.J., Baker, S., Bergeron, J., Fitchett, D., Frohlich, J., Genest, J., \& Tashakkor, A.Ya. (2016). Diagnosis, prevention, and management of statin adverse effects and intolerance: Canadian Consensus Working Group update. Can. J. Cardiol., 32 (7), S35-65. DOI: 10.1016/j. cjca.2016.01.003

24. Ivashkin, V.T., Mayevskaya, M.V., Pavlov, Ch.S., Tikhonov, I.N., Shirokova, Ye.N., \& Palgova, L.K. (2015). Klinicheskiye rekomendatsii po diagnostike i lecheniyu nealkogolnoy zhirovoy bolezni pecheni Rossiyskogo obshchestva po izucheniyu pecheni i Rossiyskoy gastroenterologicheskoy assotsiatsii [Diagnostics and treatment of non-alcoholic fatty liver disease: clinical guidelines of the Russian Scientific Liver Society and the Russian gastroenterological association]. Gepatologiya - Hepatology, 2 (16), 24-42 [in Russian].

25. Shcherbynyna, M.B., Dotsenko, N.Ya., \& Herasymenko, L.V. (2011). Vozmozhnosti primeneniya ursodeoksykholevoy kysloty (Ursosan) v hipolypidemicheskoy terapii [Possibilities of application of ursodeoxycholic acid (Ursosan) in hypolipidemic therapy]. Ukrainskyi medychnyi visnyk - Ukrainian Medical Bulletin, 7-8, 2-4 [in Russian].

26. Durazzo, M., Belci, P., Collo, A., Grisoglio, E., \& Bo, S. (2012). Focus on therapeutic strategies of nonalcoholic Fatty liver disease. Int. J. Hepatol., 2012, 464706. DOI: $10.1155 / 2012 / 464706$

27. Khajehdehi, P. (2000). Lipid-lowering effect of polyunsaturated fatty acids in hemodialysis patients. J. Ren. Nutr., 10 (4), 191-195. DOI: 10.1053/jren.2000.16326

\title{
КЛИНИКО-ЛАБОРАТОРНЫЕ ПОКАЗАТЕЛИ У ПАЦИЕНТОВ С НЕАЛКОГОЛЬНОЙ ЖИРОВОЙ БОЛЕЗНЬЮ ПЕЧЕНИ НА ФОНЕ ЭССЕНЦИАЛЬНОЙ АРТЕРИАЛЬНОЙ ГИПЕРТЕНЗИИ
}

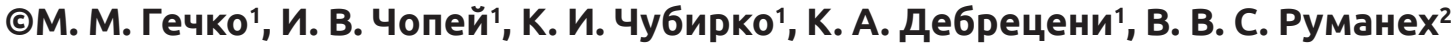 \\ ДВНЗ «Ужгородский национальный университет »' \\ Сумской государственный университет ${ }^{2}$
}

РЕзЮМЕ. Неалкогольная жировая болезнь печени (НАЖБП) является одной из самых сложных проблем современной медицины. Ее течение часто коморбидно и связано с артериальной гипертензией и метаболическим синдромом. Следует отметить, что в последние годы появилось много работ по изучению НАЖБП, но остаются неизученными вопросы относительно механизмов развития НАЖБП с эссенциальной артериальной гипертензией, показателей суточного мониторирования АД и выбора оптимального лечения, особенно с учетом хронобиологических изменений.

Цель - оптимизация диагностики и лечения НАЖХП на фоне артериальной гипертензии.

Материал и методы. Обследовано 167 больных в возрасте 28-69 лет, которые находились на амбулаторном и стационарном лечении в ГУ «Клиническая больница ст. Ужгород ГТОО «Львовская железная дорога» в течение 2010-2019 годов.

Результаты. Установлены ухудшение показателей липидного и углеводного обмена с повышением интенсивности лабораторных синдромов цитолиза и холестаза, а также изменения циркадного ритма АД у пациентов с НАЖБП на фоне АГ.

Выводы. Применение, наряду с коррекцией образа жизни и базисной терапией (аторвастатин, телмисартан и индапамид), хронотерапевтических подходов, разгрузочно-диетической терапии, адеметионина, урсодезоксихолевой кислоты у различных подгрупп пациентов с НАЖБП и АГ способствует коррекции основных отклонений исследуемых лабораторных показателей и АД.

КЛЮЧЕВЫЕ СЛОВА: неалкогольная жировая болезнь печени; артериальная гипертензия; суточный мониторинг артериального давления; разгрузочно-диетическая терапия. 
Огляди літератури, оригінальні дослідження, погляд на проблему, випадок з практики, короткі повідомлення

CLINICAL AND LABORATORY INDICATORS IN PATIENTS WITH NON-ALCOHOLIC FATTY LIVER DISEASE ON THE BACKGROUND OF ESSENTIAL ARTERIAL HYPERTENSION

\author{
@M. M. Gechko', I. V. Chopey ${ }^{1}$, K. I. Chubirko', K. O. Debreceni', W. W. S. Rumanekh² \\ Uzhhorod National University ${ }^{1}$ \\ Sumy State University²
}

SUMMARY. Non-alcoholic fatty liver disease (NAFLD) is one of the most difficult problems in modern medicine. It is often comorbid and is associated with hypertension and metabolic syndrome. It should be noted that in recent years there have been many studies on NAFLD, but questions remain about the mechanisms of NAFLD with essential hypertension, indicators of daily blood pressure monitoring and the choice of optimal treatment, especially given the chronobiological changes.

The aim - optimization of diagnosis and treatment of NAFLD on the background of arterial hypertension.

Material and Methods. 167 patients aged 28-69 years who were on outpatient and inpatient treatment in the State Institution "Departmental Clinical Hospital Art. Uzhhorod DTGO "Lviv Railway" during 2010-2019.

Results. Deterioration of lipid and carbohydrate metabolism with increasing intensity of laboratory syndromes of cytolysis and cholestasis, as well as changes in circadian rhythm of blood pressure in patients with NAFLD on the background of hypertension.

Conclusions. The use, along with lifestyle adjustments and basic therapy (atorvastatin, telmisartan and indapamide) of chronotherapeutic approaches, relief and dietary therapy, adamethionine, ursodeoxycholic acid in various subgroups of patients with NAFLD and hypertension, promotes the correction of.

KEY WORDS: nonalcoholic fatty liver disease; arterial hypertension; daily monitoring of blood pressure; unloadingdietary therapy.

Отримано 05.02.2021 